\title{
Integrating Religiosity into Fraud Triangle Theory: Findings on Malaysian Police Officers
}

\author{
Jamaliah Said \\ Accounting Research Institute \\ Universiti Teknologi MARA - Kampus Puncal Alam \\ Shah Alam, Malaysia \\ Email: jamaliah533@salam.uitm.edu.my
}

Md. Mahmudul Alam*

School of Economics, Finance and Banking

Universiti Utara Malaysia

Kedah, Malaysia

E-mail: rony000@gmail.com

Zulyanti Abdul Karim

Institute of Professional Studies

Kolej Universiti Poly-Tech MARA

Kuala Lumpur, Malaysia

Email: zulyantiabdkarim@yahoo.com

Razana Juhaida Johari

Faculty of Accountancy

Universiti Teknologi MARA

Shah Alam, Malaysia

Email: razana@salam.uitm.edu.my

* corresponding author

\section{Citation Reference:}

Said, J., Alam, M.M., Karim, Z.A., Johari, R.J. (2018). Integrating Religiosity into Fraud Triangle Theory: Findings on Malaysian Police Officers. Journal of Criminological Research, Policy and Practice, 4(2), 111-123. (online) HTTPS://DOI.ORG/10.1108/JCRPP-09-2017-0027

This is a pre-publication copy.

The published article is copyrighted by the publisher of the journal. 


\title{
Integrating Religiosity into Fraud Triangle Theory: Findings on Malaysian Police Officers
}

\begin{abstract}
Purpose - This study aims to conduct an empirical analysis of the factors that determine the occupational fraud behaviour.

Design/methodology/approach - This study utilizes primary data collected by a questionnaire based survey on 186 police officials of Malaysia including Sabah and Sarawak. Data is analysed using descriptive statistics, factor analysis, and cross-sectional regression.

Findings - The results derived in the study showed a statistically significant positive relationship between three basic variables of the fraud theory - pressure, opportunity, and rationalization with asset misappropriation. Moreover, this study revealed that religiosity is statistically significantly and negatively correlated to asset misappropriation. Therefore, the higher religiosity of an individual correlates with the lower probability involve in asset misappropriation.

Practical implications - The findings will help Anti-Corruption Commission, Enforcement Agency of Integrity Commission, Police Department, and relevant agencies from Malaysia and other countries to design policies for reducing cases of fraudulent behaviour.
\end{abstract}

Originality/value - This study is an original work based on the primary data collection.

Key words: Fraud; Asset misappropriation; Rationalization; Religiosity; Ethics; Police; Corruption; Malaysia

\section{Introduction}

An appropriate handling of fraud is one of the greatest economic burdens. The Association of Certified Fraud Examiners (ACFE, 2016) highlighted the loss of 5\% of revenues each year to fraud in an organization. The total loss caused by the cases in their study exceeded $\$ 6.3$ billion, with an average loss per case of $\$ 2.7$ million.

The ACFE classifies fraud into two groups i.e. those who committed fraud in the interests of an organization and those who perpetrated against an organization (ACFE, 2014). The top management usually commits this type of fraud for the sake of an organization. Fraudulent financial reporting is typical in this category to make false reports of better earning, to increase a company's stock price.

Frauds against an organization are known as employee embezzlement or an occupational fraud. ACFE (2014) defines occupational fraud as “...the use of one's occupation for personal enrichment through the deliberate misuse or misapplication of the employing organization's resources or assets...". ACFE then classified occupational frauds into three major categories - asset misappropriations, corruption, and financial statement fraud. In asset misappropriation, an employee steals or misuses the organization's resources, such as theft of company's cash, false billing schemes, and inflated expense reports. In corruption, an employee influences a business transaction that violates his or her duty to the employer, gaining a direct or indirect benefit, such as schemes involving bribery or conflicts of interest, illegal gratuities, and economic extortion. In financial statement fraud, an employee intentionally causes a distortion or omission of information in the organization's financial reports, such as recording fictitious revenues, understating reported expenses or artificially inflating reported assets (Said et al., 2017). 
Scholars from diverse domains reported to analyse the reason of people committing fraud. American criminologist Cressey (1950) as the pioneer, had developed a theory to figure this out. Over the years, this hypothesis has been known as the "Fraud Triangle," whose three assumptions are: 1) an opportunity of the dishonest act, 2) an incentive or pressure to do so and 3) rationalization of their actions by the fraudsters (Kassem \& Higson, 2012).

Many researchers have investigated these factors and reported mixed results (Albrecth, Albrecht \& Albrecth, 2013; Dellaportas, 2013; Slezak, 2013; Rasha Kassem, Andrew Higson, 2012; Zahra, Priem \& Rasheed, 2007). Multiple studies argued that corruption, abuse of power and discipline problems often occur because of the lack of religious values, integrity, ethical issues and the egoism of the perpetrator (Hamzah, Mustari \& Basiron, 2015; Sham \& Yusof, 2015). Furthermore, Islamic religiosity has been highlighted as one of the elements to prevent a person from committing fraud (Mohamed et al., 2013; Al-Khalifah, 1994; Bernama, 2014).

However, most of these studies focus on the factors contributing to fraud with an emphasis on the organizations of developed countries. This paper, however, aims to explore the factors that contribute to asset misappropriation among Malaysian Police officers in particular. This study selects asset misappropriation schemes because it is the most common type of occupational fraud which comprising $83 \%$ of the reported cases, followed by the corruption, $35.4 \%$ and financial statement fraud of less than $10 \%$ of the reported cases accordingly (ACFE, 2016).

The percentage and frequencies of asset misappropriation performed by employees is an alarming situation. When such practices become the culture in an organization, it causes lasting damage to the reputation and public perception towards the organization. It is easy to achieve excellence, but hard to maintain excellence when the organization's image gets tarnished by the corrupt culture.

There are strong grounds for conducting this study on Malaysian Royal Police. Malaysian Police Department is one of the enforcement agencies to ensure the success of Government Transformation Programs (GTP). 'Fighting corruption' is one of the programs in GTP in which everyone should play his or her role to address the problem of corruption in their organization as well as in the whole Malaysia. However, over the years, the Malaysian Auditor General Report revealed a string of suspected fraud cases among the police. For example, in 2012 the Auditor General Report revealed the loss of assets in the department of Logistic, Bukit Aman Police Headquarter in which 309 units of assets worth millions were reported missing. This audit finding is a shocking fact on suspected asset misappropriations happened in a public-sector agency.

\section{Literature Review and Hypotheses Development}

\subsection{The Relationship between Pressures and Asset Misappropriation}

Most experts on fraud believe in four types of pressure, (1) Financial, (2) Vices, (3) Workrelated, and (4) other pressures (Said et al., 2017). The most common financial pressures are greed, personal debt, living beyond one's' resources, high bills or poor credit, financial loss and unexpected financial needs. Vice are also linked with financial pressures, for example, addictions such as gambling, drugs, alcohol and expensive extramarital relationship. Next, 
instances of work-related pressures include not enough appreciation for job performance, disappointment with the job, fear of losing the job, being overlooked for a promotion, and feeling underpaid. Lastly, examples of the other type of pressures are a spouse insisting for an improved lifestyle or a desire to deceive the system (Albrecht et al., 2004).

Other studies (Kassem \& Higson, 2012) classifies the pressure into, (1) Personal pressure, (2) Corporate or employment pressure, and (3) External pressure. Personal pressure arises because of a sudden financial problem, lifestyle, lack of disciplined and greed. Examples of corporate or employment pressures are unfair treatment, fear of losing jobs, compensation mechanism of the company, or frustrated with work. Finally, external pressure includes a threat to business financial stability, ego, image, and reputation. 1

People have an impulse to act fraudulently if they are under severe personal financial pressure, either through ordinary "day to day" debt or because of some specific issues, such as gambling. It also could be because of greed that pushes them to take fraudulent steps to increase their wealth, or they are approached by organized criminals who threaten violence to them and their families. Further, individuals are the part of such a management teams whose bonus, pay rise or job retention depends on their ability to show increasing organizational profits and assets. Revenge also could be a factor, for example, if they perceive themselves to have wrongly passed over for promotion by their bosses. Further, it is also possible that they are thrill-seekers only with no intention for money (Turner, 2008). Most researchers agree that pressure could be a motivation to commit fraud, regarding financial, personal and work pressures.

ACFE (2014) reported that $44 \%$ of fraudsters were living beyond their means and $33 \%$ were experiencing financial difficulties. These results imply that the perpetrators have pressures in their lives, thus giving them grounds of committing fraud. A study conducted by Dellaportas (2013) showed this relationship, who interviewed four small groups of male accountants under custodial sentences for committing fraud. Through the interviews, he found that the respondents were either influenced by financial pressures such as business failure and failed investment or non-financial pressures such as anger towards the employer and seek revenge by stealing company's cash.

Another study by Zahra, Priem and Rasheed (2007) also confirmed this relationship, in which they found that pressures are the fundamental reason for fraudulent activities and there are several pressures such as society, industry and organizational pressures that can influence a person and encourage their fraudulent behaviours. Therefore, by adapting the link between pressures and asset misappropriation, the following hypothesis is proposed to explore its relationship:

\section{H1: There is a positive relationship between pressures and asset misappropriation.}

\subsection{The Relationship between Opportunity and Asset Misappropriation}

An opportunity arises when employees recognize a chance to commit the fraud without being detected. This opportunity may surface from several sources, including the poor internal checks, inadequate training, poor surveillance, lack of prosecution, inefficient anti-fraud programs, policies, and weak ethical culture. Traditionally, an opportunity has been studied solely within the context of poor internal controls, in particular concerning to the distribution 
of duties, which has gathered wider attention in the recent years (e.g., in Sarbanes-Oxley section 404 requirements) (Dominey et al., 2010).

Six factors primarily contribute to providing opportunities for individuals to commit fraud in organizations. It is the system's vulnerabilities that create opportunity, lack of controls that prevent and detect fraudulent behaviour, failure to assess the quality of performance, inability to punish fraud perpetrators, lack of access to information, ignorance, indifference, insufficiency and lack of audit trail (Albrecht et al., 2004; Albrecth, Albrecht \& Albrecth, 2013). The Committee of Sponsoring Organizations emphasized the use of five determinants of opportunity, which are: (1) The environmental control, (2) Control Activities, (3) Risk Evaluation, (4) Information and Communication Systems, (5) Monitoring the System (Root, 2000).

Many researchers argued that opportunity be one of the factors to contribute to fraudulent activities. For example, in a study by Aziz, Nor and Ahmad (2010), they observed that fraud such as misappropriation of funds, making false traveling claims, receiving kickbacks from vendors, misuse of authority on procurement issues and false signatures on cheques, happened because of the weak monitoring and surveillance from the management. Therefore, fraudsters get motivated by the weaknesses in the monitoring system, segregation of duties and presence of opportunities.

Another study by Brucker and Rebele (2010), also endorses the relationship between opportunity and asset misappropriation. Their study revealed a fraud case committed at a public authority by the authority's chief accounting officer who stole tens of thousands of dollars in cash over a period of several years. This incidence happened due to the internal control problems such as the weak authorization control, physical control over cash, ineffective separation of duties, access to cash and record-keeping. These flaws provide an opportunity to the chief accounting officer since he has the power to authorize both transactions and the payment for the transactions.

Furthermore, in a later study, Dellaportas (2013) argued that opportunity have a relationship with fraudulent activities. He found that the perpetrators used their skills and understanding of systems to manipulate and bypass control to avoid detection. For example, one of the perpetrators used his expertise on cheque-clearing protocols to commit cheque-fraud. Another offender took benefit of carelessly administered internal audit procedures to transferred money into his bank accounts for seven years. Above mentioned incidences confirm that weakness in the internal control procedures becomes an opportunity for their employees to manipulate the system's procedures. Since a weak internal control system may become an opportunity for the employees to commit fraud, following hypothesis is developed:

H2: There is a positive relationship between opportunity and asset misappropriation.

\subsection{The Relationship between Rationalization and Asset Misappropriation}

Rationalization helps the fraudster to hide from the wrongdoing of their deeds. Some of the common rationalizations are "the organizations owe me", "I am only borrowing the money", "Nobody will get hurt", "I deserve more", "it's for a good purpose", "we'll fix the books as soon as we get over this financial difficulty", and "something has to be sacrificed, either my integrity or my reputation" (Albrecth et al., 2013). Cressey (1950) concluded that most 
fraudsters believe themselves as ordinary, honest people caught in a critical situation. This plea enables to justify the crime in a way that makes it acceptable for themselves (Dellaportas, 2013). While, Dellaportas (2013) in his study also supported that offenders are aware of their immodest behaviour, but they rationalized it using three types of denials; (1) denial of accountability, (2) denial of harm, and (3) denial of victims.

Cressey (1950) explained the importance of a morally acceptable rationalization before fraudsters indulge into the crime. Because a fraudster does not see himself as a criminal, therefore he justifies his offenses to himself first. For example, the perpetrator may reconcile his actions by thinking, "This is just a loan, and I will pay it back after my next pay check." This rationalization allows the perpetrator to see illegal conduct as acceptable, thus protecting his self-image as a reliable person. Of course, in fraud, the payback of that "loan" never happens. Similar to pressure, rationalization is not a readily noticeable characteristic, because it is highly unlikely to predict someone else's thinking (Dominey et al., 2010).

Previous studies have also suggested a relation in between rationalization and fraudulent activities. Slezak (2013) conducted a study about theft among employees in New York State Public Schools. Some employees always convinced themselves with rationalizations with an opportunity. The majority of employees in their study $(57 \%)$ engaged in rationalization committed as many as 18 times. Nearly $70 \%$ of them did so for three times or more. The study exhibited that the respondents collectively used all of the nine rationalization techniques offered to them; over $46 \%$ of them admitted that the abuse of time is acceptable behaviour.

Dellaportas (2013) also observed that two of the fraudsters rationalized themselves by claiming their actions as the outcome of poor decisions. Another fraudster pretended to be an ethical person confronted with gambling addiction. Another three of the fraudster argued the victimless nature of his crime because losses incurred to the bank are recoverable from insurance companies. Empirically, these findings imply the justification of fraudulent behaviour through rationalization. Given this, the pattern of employee rationalization reported by these studies should serve as a base to develop the following hypothesis:

\section{H3: There is a positive relationship between rationalization and asset misappropriation.}

\subsection{The Relationship between Religiosity and Asset Misappropriation}

Religion is seen as a real fact of the human experience and believed to be an influential factor in the development of an individual's personality, and a critical part of life (Salleh, 2012; Hamzah, Mustari \& Basiron, 2015; Sham \& Yusof, 2015). Religiousness is defined as "believing strongly in the existence of a God or Gods." Religiosity may be related to as the state of one's belief in Allah/God, correlated by his devotion and religious enthusiasm (Salleh, 2012).

Malaysia is a Muslim majority country. Every man who claims himself as Muslim must have true belief and trust to the "Six Pillars of Iman." He must give complete and sincere faith in Allah as the creator of the universes and as the only one worthy of worship, and one's belief in his angels, messengers, books, the day of judgment \& hereafter, and in fate. They also need to commit the "Five Pillars of Islam" that is the Shahadah (testimony of Allah as the only God and Muhammad as the messenger of Allah), prayers (Salat), alms-giving (Zakat), 
fasting in Ramadhan (Sawm), and pilgrimage to Mecca (Hajj). Any Muslim that committed to the "Six Pillars of Iman," and the "Five Pillars of Islam" will never let themselves from committing fraud as they are aware that the retaliation in the hereafter would be worse and it is not the way of a Muslim life. In a simple explanation, an individual who is pious and has a firm and sound knowledge about their religion would be able to distinguish themselves from bad behaviours. Thus, he or she will avoid from engaging fraudulent activities because it is prohibited by the religion (Zawawi, Said \& Yusof, 2011; Alam, Said \& Hassan, 2015).

Previous studies have conceptualized that religiosity was significantly associated with ethical or fraudulent behaviour that the higher the religiosity, the lower the fraudulent activities. This hypothesis has been proved correct in the study of Reidenbach and Robin (1990) in which they argued that religious variables influence the moral judgment of individuals. Additionally, they proposed that more religiously committed persons give added weight to moral absolutes when evaluating situational ethical issues. They also argued that religious individuals will be better aware of ethical problems, hence, a religious individual will reject that situation which contradicts with their religious, ethical values.

Al-Khalifah (1994) in his study mentioned that religiosity, in the Islamic context, serves as a mechanism that shields people from criminal temptation, by putting the concept of law in the jurisdiction of religion. Committing a crime is a disobey of Allah's law, and by being aware of the certainty and strictness of punishment in the afterlife, criminality is kept to a minimum among Muslims. Other than that, Islam also provides a unique social control perspective such as religion, morality, and law, which enable Muslims to exhibit all moral means at various levels of human life (economic, political and personal) through which they can reach their goals.

Recent studies also support the relationship between religiosity and fraudulent activities, for example, Zawawi, Said and Yusof (2011) reported a significant negative correlation between religiousness and intentional behavioural. The finding indicated that the intention of fraudulent financial reporting is less likely among religious top-level management. Therefore, based on above findings, it is hypothesized that:

\section{H4: There is a negative relationship between religiosity and asset misappropriation.}

\section{Research Methodology}

\subsection{Data, sample and variable}

This study utilized data collected from 186 Royal Malaysian Police Officials of Malaysia including Sabah and Sarawak, based on a questionnaire survey. The samples were selected randomly and only considered the Muslim respondents. This questionnaire uses a seven-point Likert-type rating scale ranging from 1 (strongly disagree) to 7 (strongly agree).

Further, to measure asset misappropriation, respondents provided their opinion on ten different items related to the usual practice of utilizing the office assets and facilities. These items were adapted with some modification from a previous study by Majid et al. (2010). After that, to measure the opportunity, respondents provided their opinion on nine parameters of their work place internal control activities and procedures. A previously published study (Root, 2000) endorses the use of these nine parameters. The respondents also gave their opinion on pressures in life, consisting of financial and non-financial pressures inscribed in 
ten items of the survey, which are readjusted from a previous study by Kassem and Higson (2012). The respondents reported their perception or rationalization of actions in performing their jobs in ten parameters, accustomed from the previous study done by Albrecht et al. (2004). Ten survey items evaluated the respondent's level of religious belief and practice. These items were chosen with some modification from the Comprehensive Measure of Islamic Religiosity used in the previous study done by Al-Khalifah (1994). The complete list of the items (parameters) used in this study are presented in the appendix.

\subsection{Model and statistical test}

This study analyses the collected data using descriptive statistics, factor analysis, and crosssectional regression. Initially, the standard statistical procedures confirm the validity of data. Kaiser-Meyer-Olkin test checks the adequacy of data; Kolmogorov-Smirnov (K-S), ShapiroWilk tests and graphical analysis are executed to ensure the normality of data; and the homoscedasticity of data is examined by F-test and Bartlett Sphericity test. Thereafter, correlation analysis and variance inflation factor (VIF) are performed to check the multicollinearity problem. Finally, the reliability of the data is tested by using the Cronbach's alpha test.

\section{Finding and Discussion}

\subsection{Demographic information}

Among the respondents, $81 \%$ are male (Table 1). Currently, the agency has 113,666 personnel, and only $11.7 \%$ of these numbers are women (Bernama, 2014). Approximately $54.8 \%$ of the total respondents are in the age group of 20 to 30 years. Majority of the respondent $(63.4 \%)$ are married and SPM/MCE/Certificate holder $(73.7 \%)$. Further, most of the interviewees $(35.5 \%)$ hold the job position as a Corporal. As for salary ranges, $54 \%$ of the respondents are within RM1,000- RM3,000 range and only 5.4\% are above RM5,000. About $38.7 \%$ of the respondents have been working with Royal Malaysian Police Department since last 11 years. Thus, the survey was conducted among experienced respondents, who have the adequate understanding of work procedure in their field.

Table 1: Demographic Profiles of the Respondents

\begin{tabular}{clcc}
\hline Types & Description & Frequency & Percent (\%) \\
\hline \multirow{2}{*}{ Gender } & Male & 152 & 81.7 \\
& Female & 34 & 18.3 \\
\hline \multirow{5}{*}{ Age Group } & Under 20 years & 2 & 1.1 \\
& 20 to 25 years & 30 & 16.1 \\
& 26 to 30 years & 72 & 38.7 \\
& 31 to 35 years & 24 & 12.9 \\
& 36 to 40 years & 16 & 8.6 \\
& 41 to 50 years & 26 & 14 \\
& 51 years and above & 16 & 8.6 \\
\hline \multirow{2}{*}{ Marital } & Single & 64 & 34.4 \\
Status & Married & 118 & 63.4 \\
& Widow & 4 & 2.2 \\
\hline Education & SPM/MCE/Certificate & 137 & 73.7 \\
level & Diploma & 19 & 10.2 \\
\hline
\end{tabular}




\begin{tabular}{|c|c|c|c|}
\hline & Degree & 28 & 15.1 \\
\hline & Master degree & 2 & 1.1 \\
\hline \multirow{7}{*}{ Job Position } & Constables & 36 & 19.4 \\
\hline & Lance Copral & 34 & 18.3 \\
\hline & Copral & 66 & 35.5 \\
\hline & Sergeant & 16 & 8.6 \\
\hline & Sergeant Mejar & 4 & 2.2 \\
\hline & Inspector & 20 & 10.8 \\
\hline & Others & 10 & 5.4 \\
\hline \multirow{5}{*}{$\begin{array}{l}\text { Average } \\
\text { Monthly } \\
\text { Income }\end{array}$} & RM1,000 - RM2,000 & 44 & 23.7 \\
\hline & RM2,001 - RM3,000 & 56 & 30.1 \\
\hline & RM3,001 - RM4,000 & 52 & 28 \\
\hline & RM4,001 - RM5,000 & 24 & 12.9 \\
\hline & RM5,001 and above & 10 & 5.4 \\
\hline \multirow{5}{*}{$\begin{array}{l}\text { Year of } \\
\text { services }\end{array}$} & Less than 1 year & 4 & 2.2 \\
\hline & $1-3$ years & 42 & 22.6 \\
\hline & $4-5$ years & 24 & 12.9 \\
\hline & $6-10$ years & 44 & 23.7 \\
\hline & 11 years and above & 72 & 38.7 \\
\hline
\end{tabular}

\subsection{Correlation analysis}

Correlation examines the relationship between two variables in a linear fashion (Coakes et al., 2008). This analysis helps to identify to what extent one variable is related to another. Before analysing the model, the correlation analysis examines the relationship between the variables. For this study, a Pearson Correlation test is used to ascertain the absence of any multicollinearity problem in the data. Two variables that are highly correlated to each other and explain the dependent variable, cause a multicollinearity problem if the value of the coefficient is 0.8 or 0.9 , and above (Field, 2000).

Table 2: Correlation Analysis

\begin{tabular}{ccccc}
\hline & Pressure & Rationalisation & Opportunity & Religiosity \\
\hline Asset Misappropriation & $.370^{* *}$ & $.606^{* *}$ & $.214^{* *}$ & $-.251^{* *}$ \\
Sig. (2-tailed) & .0000001 & .0000001 & .003 & .001 \\
$\mathrm{~N}$ & 186 & 186 & 186 & 186 \\
\hline
\end{tabular}

** indicates significance at the $1 \%$ level (2-tailed).

Table 2 summarises the results of the bivariate analysis performed to test the correlation between one variable to another. The statistical results show that the correlation values among the variables range between -0.20 and 0.60 . These values indicate the absence of multicollinearity problem among the variables since none of the correlation is more than 0.8 . The results also explicate a statistically significant positive relationship between pressure, opportunity, rationalization with asset misappropriation and a negative correlation between religiosity and asset misappropriation.

\subsection{Regression analysis}

The $\mathrm{R}^{2}$ value indicates that $42 \%$ of the asset misappropriation can be explained by this model (Table 3). According to Pallant (2007), there is a possibility of multicollinearity if the VIF 
value is above 10, but in this study the range of the VIF values lies in between 1.082 and 1.257 , indicating the absence of multicollinearity among the variables.

Table 3: Regression Analysis

\begin{tabular}{llllll}
\hline Variables & Coefficient & Std. Error & t-statistic & p-value & VIF \\
\hline Constant & .925 & .539 & 1.718 & .087 & \\
Pressure & .111 & .055 & 2.000 & .047 & 1.237 \\
Opportunity & .142 & .072 & 1.980 & .049 & 1.082 \\
Rationalisation & .381 & .047 & 8.170 & .000 & 1.257 \\
Religiosity & -.149 & .070 & -2.129 & .035 & 1.095 \\
\hline $\mathrm{R}$ & & & .647 & & \\
$\mathrm{R}^{2}$ & & & .418 & & \\
Adjusted R $^{2}$ & & & .405 & & \\
Std. Error of the Estimate & & & .722 & & \\
\hline
\end{tabular}

The regression output implies a statistically significant and positive relationship between pressure and asset misappropriation. These results further endorses the finding of Zahra, Priem and Rasheed (2007), in which they stated that there are several pressures such as society, industry and organizational pressures that can influence managers to commit fraud. The results obtained also support the study of Dellaportas (2013), who agreed that the accountants which were serving custodial sentences for committing fraud, were influenced by financial pressures and non-financial pressures. This study recommends that whenever a person gets stuck in a non-shareable problem situation, whether the financial or non-financial problem, he is more prone to commit fraud.

The regression output shows a statistically insignificant positive relationship between opportunity and asset misappropriation. This result exhibits a similar finding with Brucker and Rebele (2010), in which chief accounting officer of a public authority stole tens of thousands of dollars in cash over a period of several years. The offender got such opportunity because of his authority to approve transactions and its payment both.

The result also supports the study of Dellaportas (2013) who suggested a positive link between opportunity and fraud; in case of asset misappropriation, he found that a weak internal control system offers an opportunity to the perpetrators to use their knowledge to manipulate the systems without being detected. Therefore, it is obvious that a significant relationship exists between opportunity and asset misappropriation among Royal Malaysian Police Officials.

The regression output also shows a statistically insignificant positive relationship between rationalization and asset misappropriation. Previous studies indicate that most of the fraudsters were aware of their improper behaviour, but they rationalized their fraudulent conduct. This result confirms the conclusion of the previous study by Dellaportas (2013). He argued that the fraudsters rationalized themselves by justifying their act either as a poor decision or considering that their crime was victimless. This study also found the highest coefficient for rationalization, indicating the highest influences on asset misappropriation than other four variables.

Finally, the regression output shows statistically insignificant but negative relationship between religiosity and asset misappropriation. This result has a similar finding with Zawawi, Said and Yusof (2011) who revealed a significant negative relationship between religiousness and fraud behaviour. He observed that the intention of fraudulent financial reporting is less 
likely among the religious top-level management. This study also ascertains that the higher religiosity of an individual, the lower probability of him or her to be involved in asset misappropriation.

\subsection{Diagnostic Test}

To ensure the normal distribution of data, this study uses Kolmogorov-Smirnov (K-S) and Shapiro-Wilk tests. In K-S and Shapiro-Wilk test, a significant value (sig < 0.05 ) indicates a deviation from normality (Table 4). The result shows all the variables are highly significant, indicating that the distribution is not normal. However, K-S test and Shapiro-Wilk test have their limitations with a large population size that is assumed to be a normal distribution (Pallant, 2007).

Table 4: Test of Normality

\begin{tabular}{lcccccc}
\hline & \multicolumn{3}{c}{ Kolmogorov-Smirnov } & \multicolumn{3}{c}{ Shapiro-Wilk } \\
\cline { 2 - 7 } & Statistic & df & Sig. & Statistic & df & Sig. \\
\hline Asset Misappropriation & .201 & 186 & .000 & .819 & 186 & .000 \\
Opportunity & .093 & 186 & .000 & .966 & 186 & .000 \\
Pressures & .105 & 186 & .000 & .971 & 186 & .001 \\
Rationalization & .190 & 186 & .000 & .886 & 186 & .000 \\
Religiosity & .111 & 186 & .000 & .910 & 186 & .000 \\
\hline
\end{tabular}

Further, a missing normal bell shaped curves in histograms (Figure 1) symbolizes non-normal distribution of data. However, Vaus (2002) affirmed that for a large population size (exceeding 100), even with the non-normal distribution of the data, it is reasonable to use statistics that assume a normal distribution.
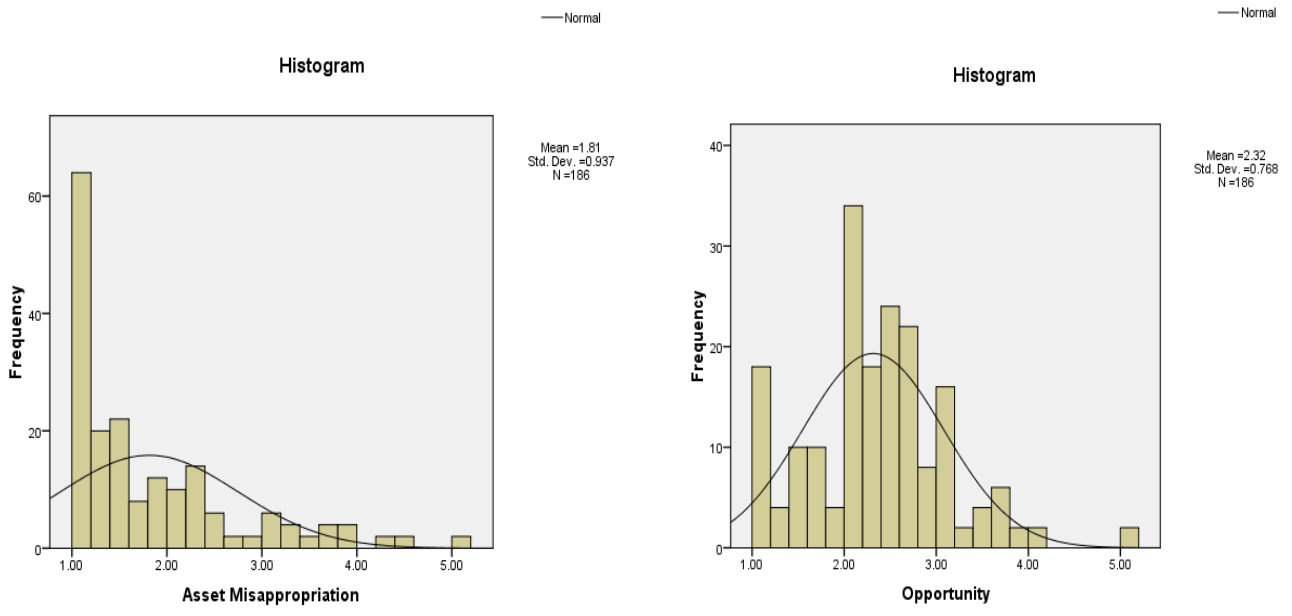


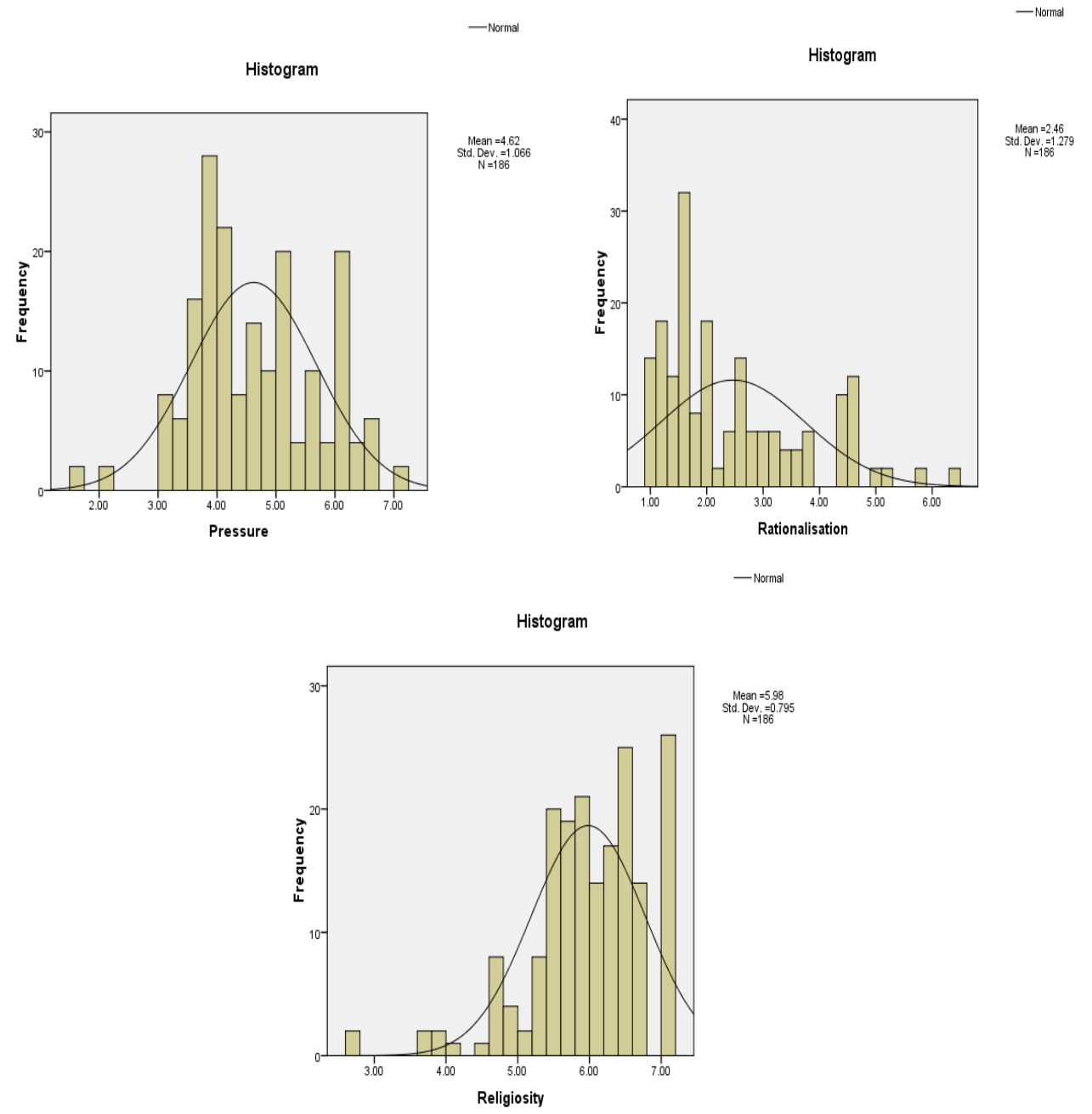

Figure 1: Histogram and Distribution of Data

Reliability analysis looks at the internal consistency and stability of the measuring instrument. Cronbach's alpha coefficient is commonly used as the internal consistency indicator. The ideal value of Cronbach's alpha coefficient differs among the studies. Nunnally (1978, p.226) suggests a modest reliability ranging between 0.50 and 0.60 would suffice for an initial study. Loewenthal (2004) mentions the value of 0.60 could be acceptable. Hair et al. (2010) mention that the accepted lower limit for Cronbach's alpha may reduce to 0.60 in exploratory research. Pallant (2007) mentions it should be above 0.70 . The results of Cronbach's alpha for all of the five variables are more than 0.80 , which means all the items are reliable (Table 5).

Table 5: Reliability Test for Parameters

\begin{tabular}{lccccc}
\hline Measurement & $\begin{array}{c}\text { Asset } \\
\text { Misappropriation }\end{array}$ & Opportunity & Pressure & Rationalisation & Religiosity \\
\hline Cronbach's Alpha & 0.883 & 0.821 & 0.838 & 0.835 & 0.844 \\
Eigenvalue & 5.084 & 4.329 & 4.197 & 3.042 & 4.33 \\
& 1.336 & 1.249 & 1.472 & & 1.608 \\
& & & 1.153 & & 1.023 \\
Eigen \% variance & 64.198 & 61.98 & 68.226 & 60.844 & 69.615 \\
\hline
\end{tabular}


Kaiser-Meyer-Olkin Measure of

Sampling Adequacy

Bartlett's Test of Sphericity

Approx. Chi-Square

Df

Sig.
0.802

1073

45

0.00000
$0.814 \quad 0.796$

0.735

0.719

Moreover, by using the varimax rotations, an exploratory factor analysis, and principal components analysis identify the correlation between variables and sampling adequacy. The factor analysis gives the consistency measures of these variables to estimate opportunity, pressure, rationalization, religiosity, and asset misappropriation. The factor loadings for most of the variables are more than 0.60 (Appendix Table). The Kaiser-Meyer-Olkin coefficient for this dataset is more than 0.71 (Table 5) that exceed the recommended value of 0.60 (Tabachnick \& Fidell, 2006), justifying the subsequent use of exploratory factor analysis (Hair et al., 2010). Furthermore, to test the homoscedasticity or homogeneity of variances, the Bartlett Sphericity test is conducted where the values all five variables are noted to be statistically significant, supporting the factorability of the correlation matrix (Pallant, 2007).

\section{Conclusion}

This study aims to explore the cause and effect relationships of four variables namely pressure, opportunity, rationalization, and religiosity in influencing or preventing asset misappropriation among Royal Malaysian Police Officials. The results derived here infer a significant role of pressure, opportunity and rationalization of staff members to commit fraud, while religiosity acts as a prevention mechanism.

The pressure of life, especially a financial problem when perceived as unshareable leaves an individual in a desperate situation. Some individual might lose their sanity or judgment, and to solve their problem they commit fraud. Further, an opportunity also contributes to one's involvement in the fraud as supported by the hypothesis on a positive relationship between opportunity and asset misappropriation. The findings of this study emphasize on controlling the activities and operation through designated regulation and procedure to guarantee a lower fraudulent activity among Royal Malaysian Police Officials. Moreover, the result indicates a positive relationship between rationalization and fraud.

The results of this study demonstrate the typical characteristics of a fraudster to make serial of excuses and rationalization for getting rid of the guilt feeling. Furthermore, the result establishes a negative relationship between religiosity and fraudulent activities. It has been hypothesized that higher the religiosity of an individual, the lower probability of him or her to be involved in fraud. Thus, this study concludes that religiosity could be used as a mechanism of deterring the officials to commit misconduct.

Finally, the findings of this study indicate that some of the police officials have been alleged to practise misconduct as a norm in their daily role. Although this number is only a small portion (less than 1\%), these people are tarnishing the reputation of the entire enforcement agency. Hence, the department should implement a more systematic internal control to build the confidence among the stakeholders and upgrade their level of integrity. They also need to be equipped with adequate level of religious knowledge to deter them from involving in fraud. The Division of Religion and Counselling (BAKA) in Royal Malaysian Police Department could use the findings of this study to establish consistent and continuous 
programmes that could enhance the religious knowledge among the officials so that they could integrate religion as their way of life, especially at the time of performing their responsibilities as police officials.

There are some limitations of the study, and those might be improved in future studies. This study uses data only from the Muslim police officials; as a result, the perceptions from other religious groups may differ. Moreover, this study focuses on the perspective of a police official as an individual, and taking that aspect, future studies should explore the outcomes from the organisational perspectives based on a large scale and longer time frame of research.

\section{References}

Alam, M. M., Said, J., \& Hassan, S. (2015). Performance of Islamic Microcredit in Terms of Maqasid Al-Shariah: Case Study on Amanah Ikhtiar Malaysia. Humanomics. 31(4), 374-384.

ACFE, (2016). Report to the Nation on Occupational Fraud and Abuse 2016 Global Fraud Study. Published by Association of Certified Fraud Examiners, US.

ACFE, (2014). Report to the Nation on Occupational Fraud and Abuse 2014 Global Fraud Study. Published by Association of Certified Fraud Examiners, US.

Albrecht, W. S., Albrecht, C. O. Albrecht C. C. \& Zimbelman M.F.(2004). Fraud Examination \& Prevention. United States America: Thomson South-Western.

Albrecht, W. S., Albrecht, C. O., \& Albrecht, C. C. (2013). Current Trends In Fraud and its Detection. Information Security Journal: A Global Perspective, 17(2), 1-12.

Al-Khalifah, A. H. M. (1994). Religiosity in Islam as a Protective Mechanism against Criminal Temptation. The American Journal of Islamic Social Sciences, 11(1), 1-10.

Aziz, A. A., Nor, A. M., \& Ahmad, S. N. S. (2010). Fraud in Federal Statutory Bodies. Paper presented at the 2010 International Conference on Financial Theory and Engineering, Shah Alam. Malaysia.

Bernama. (2014, August 14). Bernama. from http://www.bernama.com.my

Brucker, W. G., \& Rebele, J. E. (2010). Fraud at Public Authority. Journal of Accounting Education, 28(1), 26-37.

Coakes, S.J., Steed, L., \& Price, J. (2008). SPSS version 15.0 for windows: Analysis without Anguish. John Wiley \& Sons Australia Ltd.

Dellaportas, S. (2013). Conversations with inmate accountants: Motivation, opportunity and the fraud triangle. Accounting Forum, 37(1), 29-39.

Dominey, J. W., Fleming, A. S., Kranacher, M.-J., Riley R., (2010). Beyond The Fraud triangle: Enhancing Deterrence of Economic Crime. The CPA Journal,80(7), 17-24.

Field, A. (2000). Discovering Statistics using SPSS for Windows Sage Publications. London, page 2, 44-322.

Hair, J., Black, W., Babin, B., Anderson, R., \& Tatham, R. (2010). Multivariate Data Analysis $\left(7^{\text {th }}\right.$ ed.). Uppersaddle River, N.J.: Pearson Prentice Hall.

Hamzah N., Mustari M., I., \& Basiron B. (2015). Model Pendidikan Kerohanian Terhadap Anak-Anak dalam Kalangan Wanita Cemerlang Sektor Awam. Global Journal AlThaqafah, 5(1), 105-11

Kassem, R., \& Higson, A. (2012). The New Fraud Triangle Model. Journal of Emerging Trends in Economic and Management Sciences, 3(3), 191-195.

Kline. (1995). The survey research handbook New York: Pearson.

Kline. (1999). A Handbook of Test Construction. New York: Methuen.

Majid, R. A., Mohamed, N., Abdullah, A., \& Mahmud, Z. (2010). An Exploratory Study on the Possibility of Misappropriation of Assets Occurring in a Local Authority. Paper 
presented at the 2010 International Conference on Science and Social Research (CSSR 2010), Kuala Lumpur, Malaysia.

Nunnally. (1978). Psycometric Theory. New York: McGraw-Hill.

Pallant, J. (2007). SPSS Survival Manual (3 ${ }^{\text {rd }}$ ed.). New York: McGraw-Hill Education.

Reidenbach, R. E., \& Robin D. P. (1990). "Toward the Development of a Multidimensional Scale for Improving Evaluations of Business Ethics." Journal of Business Ethics 9 (8): 639-653.

Root, S. (2000). Beyond COSO: Internal Control to Enhance Corporate Governace. Los Angeles: John Wiley \& Sons.

Said, J., Alam, M.M., Ramli, M., \& Rafidi, M. (2017). Integrating Ethical Values into Fraud Triangle Theory in Assessing Employee Fraud: Evidence from the Malaysian Banking Industry. Journal of International Studies, 10(2), 170-184.

Salleh, M. S. (2012). Religiosity in Development: a theoretical Construct of an Islamic-Based Development. International Journal of Humanities and social science, 2(14), 266274.

Schuchter, A., \& Levi, M. (2013). The Fraud Triangle Revisited. Security Journal, 1-15.

Sham F.,M., Yusof S. (2015), Religiosity of Muslim Adolescents from Single Parent Families Living in Government-Subsidised Settement. Global Journal Al-Thaqafah, 5 (2), 1-12.

Slezak, K. (2013). Fraud Prevention and Employee Rationalization in New York State Public School. Ph.D, State University of New York, 48-49.

Tabachnick, G. B., \& Fidell, L. S. (2006). Using Multivariate statistic (5th Edn). Boston: Pearson Education. Ally \& Bacon Inc, USA.

Turner, C. (2008). Fraud Risk Management. A practical guide for Accountant. United Kingdom: CIMA.

Vaus, D. A. (2002). Survey in Social Research. $5^{\text {th }}$ Edition.Sydney: Allen \& Unwin publisher.

Zahra, S. A., Priem, R. L., \& Rasheed, A. A. (2007). Understanding the Causes and Effects of Top Management Fraud. Organizational Dynamics, 36(2), 122-139. doi: 10.1016/j.orgdyn.2007.03.002

Zawawi, S. N. H. M., Said, J., \& yusof, S. N. S. (2011). Intention Towards Fraudulent Financial Reporting: Recent Evidence From Emerging Economy. Archives Des Sciences Journal 65(6), 1-12. 


\section{Appendix:}

\section{List of variables}

\begin{tabular}{|c|c|c|}
\hline $\begin{array}{c}\text { Dimensions/ } \\
\text { Variables }\end{array}$ & Items/ Parameters. & $\begin{array}{l}\text { Factor } \\
\text { Loading }\end{array}$ \\
\hline \multirow{10}{*}{ 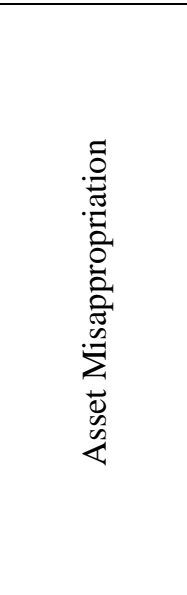 } & I usually used an office vehicle for personal reasons. & 0.622 \\
\hline & I usually used office internet services for personal purposes. & 0.840 \\
\hline & I usually used some of the uniforms given inappropriately. & $0.523 *$ \\
\hline & $\begin{array}{l}\text { I usually took some of the office assets without superior permission. Such as handcuffs } \\
\text { and weapons. }\end{array}$ & 0.688 \\
\hline & $\begin{array}{l}\text { I usually bring home some of the office assets for personal use. Such as, handcuffs and } \\
\text { weapons. }\end{array}$ & 0.706 \\
\hline & I usually add extra hours to the actual hours worked for overtime claim. & $0.514 *$ \\
\hline & I usually file for traveling expenses for personal traveling. & 0.659 \\
\hline & I usually file for fictitious medical expenses. & 0.687 \\
\hline & I usually used office computer and printer for personal purpose. & 0.826 \\
\hline & I usually borrowed office petty cash money for personal used. & $0.355^{*}$ \\
\hline \multirow{9}{*}{ 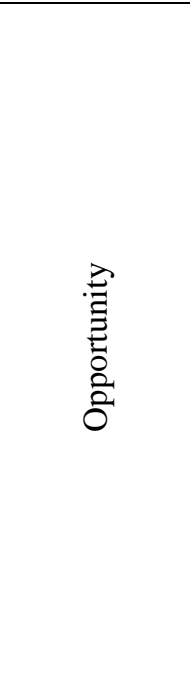 } & $\begin{array}{l}\text { In my department, there is proper segregation of duties that prevents just one employee } \\
\text { to be responsible for recording and processing a transaction. }\end{array}$ & $0.580^{*}$ \\
\hline & $\begin{array}{l}\text { In my department, there is a proper authorization of claim relating to travel, } \\
\text { accommodation and meal allowances. }\end{array}$ & 0.697 \\
\hline & $\begin{array}{l}\text { In my department, there is proper supervision, monitoring, and review of staff work } \\
\text { and responsibilities. }\end{array}$ & 0.663 \\
\hline & $\begin{array}{l}\text { In my department, there is proper physical control, for example, proper authorization } \\
\text { for use of assets such as vehicle and weapons. }\end{array}$ & 0.691 \\
\hline & $\begin{array}{l}\text { In my department, there is proper supervision over usage of organization's facilities } \\
\text { such as telephones and internet connections. }\end{array}$ & $0.489 *$ \\
\hline & In my department, there is proper record regarding employees claim. & 0.655 \\
\hline & In my department, there is a proper record for all assets in the organization. & 0.708 \\
\hline & $\begin{array}{l}\text { In my department, there is proper supervision to avoid employees from abusing the } \\
\text { medical certificate. }\end{array}$ & $0.447 *$ \\
\hline & In my department, there is proper supervision over organization's petty cash flow. & 0.648 \\
\hline \multirow{11}{*}{ 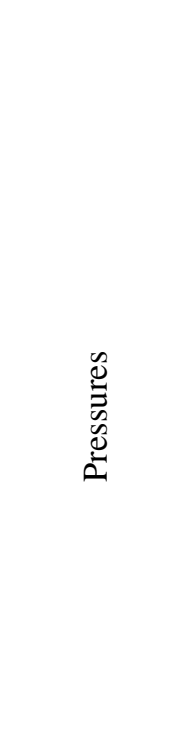 } & The increasing costs of living nowadays make me stress. & 0.661 \\
\hline & $\begin{array}{l}\text { Daily expenses need to be cut off to ensure that my salary will be sufficient until the } \\
\text { end of the month. }\end{array}$ & 0.704 \\
\hline & I need a part time job to support my monthly expenses. & 0.804 \\
\hline & $\begin{array}{l}\text { Medical bills nowadays are extremely expensive, which sometimes I couldn't afford to } \\
\text { pay. }\end{array}$ & 0.651 \\
\hline & Costs of my vehicle's maintenance nowadays are extremely high. & 0.606 \\
\hline & $\begin{array}{l}\text { I need to ensure that I am always connected with the online social media, such as } \\
\text { Facebook, Twitter and Instagram. }\end{array}$ & 0.740 \\
\hline & $\begin{array}{l}\text { It is important to me to maintain a certain lifestyle like spending on expensive things, } \\
\text { branded and luxuries. }\end{array}$ & 0.731 \\
\hline & I have huge responsibilities to support my family financially. & $0.510 *$ \\
\hline & $\begin{array}{l}\text { Sometimes, I need to hold my monthly debt payment since I don't have enough cash to } \\
\text { pay. }\end{array}$ & 0.693 \\
\hline & $\begin{array}{l}\text { It's hard to meet the key performance indicator (KPI), which will affect my bonus and } \\
\text { salary increment. }\end{array}$ & \\
\hline & & 0.721 \\
\hline
\end{tabular}


I believe that borrowing money from petty cash is a norm because everybody is doing the same.

There is no one will be suffering if I used the office facilities for personal purpose.

0.728

I am just borrowing the asset of the office, and I will return it back when I am done.

0.723

I am using the office asset for a good purpose even it is for my personal use.

I believe in Allah SWT and committed to performing principle believe set forth by Allah.

All my actions influenced by Prophets Muhammad's SAW 'Sunna'.

I always make sure my action follows the direction stated in Qur'an as all my bad and good deeds will be recorded by the Angels.

I make sure I attended religious classes at least once a week.

* The factor loadings of the parameters less than 0.6 are excluded to measure the variable 